\title{
HIDROPONIK FODDER JAGUNG SEBAGAI SUBSTITUSI HIJAUAN PAKAN TERNAK DITINJAU DARI PRODUKTIVITAS SUSU KAMBING SAPERA
}

\author{
Hydroponic Agriculture Maize Fooder as Feed Substitution on Livestock to Increase \\ Sapera`s Goat Production
}

\author{
Amung Logam Saputro ${ }^{1 *}$, Iwan Sahrial Hamid², Ragil Angga Prastiya ${ }^{3}$, \\ Muhammad Thohawi Elziyad Purnama ${ }^{4}$ \\ ${ }^{1}$ Departemen Klinik Veteriner, \\ ${ }^{2}$ Departemen Kedokteran Dasar Veteriner, \\ ${ }^{3}$ Departemen Reproduksi Veteriner, \\ ${ }^{4}$ Departemen Anatomi Veteriner, \\ Fakultas Kedokteran Hewan, Universitas Airlangga, \\ Kampus C Mulyorejo, Surabaya, Jawa Timur, Indonesia, 60115 \\ Telp. (031)5993016, Fax. (031)5993015 \\ *Corresponding author: amunglsaputro@gmail.com
}

\begin{abstract}
Abstrak
Hidroponik adalah sistem bercocok tanam menggunakan media cair dan nutrisi-nutrisi yang diperlukan untuk pertumbuhan tanaman. Keuntungan bercocok tanam dengan hidroponik yakni tanaman tidak merusak tanah, tidak membutuhkan tempat yang luas, tanpa pestisida atau obat hama yang merusak tanah, mempercepat pertumbuhan dan menjaga kualitas tanaman. Penelitian ini menggunakan perbandingan konsentrat dan fodder jagung yakni P1 (100:0), P2 (60:40), P3 (75:25) dan P4 (0:100). Hasil penelitian menunjukan bahwa kuantitas susu pada hari ke-1, ke-2 dan ke-3 menunjukkan P4 berbeda nyata $(\mathrm{p}<0,05)$ dengan P1, P2, dan P3. Hal ini menunjukkan penurunan kuantitas susu pada P4 dan kuantitas susu terbanyak pada P1 dan P3. Simpulan penelitian perlakuan pemberian fodder jagung 25\% dan konsentrat $75 \%$ serta perlakuan konsentrat 100\% dapat meningkatkan kuantitas susu kambing Sapera.
\end{abstract}

Kata kunci: fodder jagung, substitusi, produksi susu, kambing Sapera

\section{Abstract}

Hydroponic is farming system that use water medium and all important nutrition for plant. The benefit farming using hydroponic, ie no need more land, no need pesticide, chemical agents that cause land pollution, growing faster and maintenance plant quality. This study used percentage of concentrate and maize fooder, ie P1 (100:0), P2 (60:40), P3 (75:25) and P4 (0:100). The result of this study showed highly significance between $P 4$ with $P 1, P 2$ and $P 3$ at $1^{\text {st }}, 2^{\text {nd }}$ and $3^{\text {rd }}$ day milk production. Milk production showed highly at $P 1$ and $P 3$. The conclusion of this study was $P 3$ (concentrate $75 \%$ and maize fooder 25\%) and P1 (concentrate 100\%) could be substitution to increase Sapera milk production.

Key words: maize fooder, substitution, milk production, Sapera's goat

\section{PENDAHULUAN}

Salah satu faktor penting yang menentukan keberlanjutan peternakan ternak ruminansia oleh petani kecil di negara tropis seperti Indonesia adalah suplai secara konsisten sumber pakan yang murah tetapi mempunyai nilai nutrisi yang tinggi. Kurangnya ketersediaan dan juga fluktuasi dalam jumlah dan kualitas sumber pakan yang terjadi sepanjang tahun akan berpengaruh pada produktivitas ternak yang berpengaruh pada keuntungan yang didapat dari hasil beternak (Yulistiani, 2012).

Alternative yang dapat dilakukan dengan mengembangkan strategi pembuatan pakan berbasis hidroponik dan meningkatkan penggunaannya. Sumber pakan dari pemanfaatan pertanian, hijauan pepohonan dan limbah-limbah hijauan merupakan sumber pakan penting untuk ternak ruminansia di daerah tropis karena tidak bersaing dengan kebutuhan pangan manusia. Limbah pertanian seperti jerami, daun kelapa 
sawit sangat banyak tersedia di berbagai daerahdaerah tertentu, namun pakan tersebut mempunyai nilai kualitas yang rendah. Peningkatan pakan konsentrat yang diimpor merupakan cara yang paling mudah serta paling cepat dapat dilihat pengaruhnya pada produktivitas ternak. Tetapi cara ini kurang dapat diterima oleh peternak kecil karena harganya yang mahal dan tidak terjangkau. Sebagai alternatif pengganti pakan konsentrat impor, dapat diberikan suplementasi pakan hijauan dari jenis leguminosa dan non-leguminosa pohon yang mempunyai nilai nutrisi yang tinggi karena mempunyai kandungan protein yang tinggi sehingga dapat dipakai sebagai sumber protein terutama pada musim kemarau. Kondisi iklim tropis memberikan kelebihan pada tanaman pakan ternak terutama hijauan dari pohonan yang dapat tumbuh subur sepanjang tahun. Beberapa hijauan leguminosa pohon dan semak pada umumnya mempunyai kandungan protein yang tinggi sekitar 20-30\% (Leng, 1997).

Beberapa tahun terakhir peningkatan ketertarikan untuk menggunakan teknologi hidroponik untuk menghasilkan pakan dengan kualitas yang bagus seperti penanaman azzola ataupun fodder jagung secara hidroponik. Ketertarikan ini antara lain disebabkan oleh potensi produksi hijauan yang semakin lama semakin sulit, nilai nutrisi dan palatabilitas pakan terhadap produktivitas ternak ruminansia khususnya kambing sapera (Sanchez, 2002).

Kambing sapera merupakan salah satu kambing penghasil susu dari Indonesia. Kambing sapera merupakan kambing silangan dari kambing Saanen Full Blood dari Swiss dengan kambing Peranakan Etawa dari Indonesia. Hasil silangan dari kedua kambing diharapkan dapat menghasilkan produksi susu yang maksimal dengan kualitas yang baik serta diharapkan sebagai penghasil daging dengan perfoma morfologis jauh lebih besar dari kambing Saanen murni. Dengan demikian perlu dilakukan pemahaman lebih lanjut tentang pemanfaatan hidroponik fodder jagung sebagai pengganti hijauan pakan ternak yang dapat menunjang perfoma produktivitas susu kambing Sapera dengan kualitas yang bagus.

\section{METODE PENELITIAN}

Penelitian dilaksanakan di peternakan "Bumi Kesilir Farm", Desa Kesilir Kecamatan Siliragung Kabupaten Banyuwangi dan Laboratorium Fakultas Kedokteran Hewan PSDKU Universitas Airlangga Banyuwangi. Ternak yang digunakan dalam penelitian ini adalah kambing Sapera dengan kondisi laktasi antara laktasi satu dan laktasi kedua. Kambing yang digunakan memiliki produksi rata-rata 1 liter/hari.

Bahan yang digunakan dalam penelitian ini adalah pakan kambing perah yang terdiri atas rumput gajah odot (Pennisetum purpureum), fodder jagung hidroponik, konsentrat dan air. Rumput gajah odot diperoleh dari kebun Bumi Kesilir Farm dan fodder jagung disemai pada nampan-nampan yang telah dimodifikasi sehingga bisa digunakan secara hidroponik.

Alat-alat yang dipergunakan meliputi kandang kambing laktasi, ember plastik, peralatan perah, ember plastik, gelas ukur, penyaringan susu, milk can, lap bersih, dan plastik pengemas. Fodder jagung dibawa ke Balai Perikanan Kabupaten Banyuwangi untuk dianalis proksimat dan susu dibawa ke Laboratorium Kesehatan Masyarakat Veteriner PSDKU Universitas Airlangga Banyuwangi.

Pakan yang diberikan terdiri atas perbandingan konsentrat dan fodder jagung yakni P1 (100:0), P2 (60:40), P3 (75:25) dan P4 $(0: 100)$. Konsentrat diberikan terlebih dahulu setelah pemerahan pagi dan dilanjutkan pemberian hijauan 30 menit setelahnya.

Peubah yang diamati yaitu Produksi susu (kg/ekor/hari) dan hasil analisis proksimat dari fodder jagung. Produksi susu diperoleh dengan cara mencatat hasil pemerahan kambing Sapera masing-masing pagi dan sore. Pengukuran dilakukan setelah masa persiapan sampai masa akhir penelitian. Pengukuran produksi dilakukan menggunakan gelas ukur.

Data yang diperoleh diolah menggunakan analisis ragam Analysis of Variance (Anova) dengan dilanjutkan uji Duncan jika terdapat hasil yang signifikan $(p<0,05)$. 


\section{HASIL DAN PEMBAHASAN}

Hasil penelitian kandungan fodder jagung sebagai pengganti hijauan terhadap kuantitas susu kambing Sapera yang diperah pada hari ke1, ke-2 dan ke-3 dapat dilihat pada tabel 1 dan 2 berikut:

Tabel 1. Hasil kuantitas susu kambing Sapera setelah pemberian fodder jagung

\begin{tabular}{rrrr}
\hline \multirow{2}{*}{ Perlakuan } & \multicolumn{3}{c}{ Mean \pm SD } \\
\cline { 2 - 4 } & \multicolumn{1}{c}{ Hari ke-1 } & \multicolumn{1}{c}{ Hari ke-2 } & \multicolumn{1}{c}{ Hari ke-3 } \\
\hline P1 & $20^{\mathrm{a}} \pm 44,720$ & $40^{\mathrm{a}} \pm 54,770$ & $0^{\mathrm{a}} \pm 212,13$ \\
P2 & $-120^{\mathrm{a}} \pm 83,670$ & $-60^{\mathrm{a}} \pm 65,190$ & $-140^{\mathrm{a}} \pm 74,160$ \\
P3 & $-90^{\mathrm{a}} \pm 102,47$ & $40^{\mathrm{a}} \pm 167,33$ & $-100^{\mathrm{a}} \pm 122,47$ \\
P4 & $-520^{\mathrm{b}} \pm 144,05$ & $-490^{\mathrm{b}} \pm 174,64$ & $-530^{\mathrm{b}} \pm 228,04$ \\
\hline
\end{tabular}

Keterangan : Superskrip berbeda pada kolom yang sama menunjukan hasil yang berbeda nyata $(\mathrm{p}<0,05)$

Tabel 2. Hasil analisa proksimat fodder jagung dengan penyiraman air

\begin{tabular}{cccc}
\hline Kadar Lemak & Kadar Protein & Kadar Air & Kadar Abu \\
\hline 0,41 & 3,46 & 88,99 & 0,43
\end{tabular}

Berdasarkan hasil penelitian menunjukan bahwa kuantitas susu pada hari ke-1 menunjukkan $\mathrm{P} 4$ berbeda nyata $(\mathrm{p}<0,05)$ dengan P1, P2 dan P3. Hal ini menunjukkan penurunan kuantitas susu pada P4 dan kuantitas susu terbanyak pada P1. Kuantitas susu pada hari ke-2 menunjukkan $\mathrm{P} 4$ berbeda nyata $(\mathrm{p}<0,05)$ dengan P1, P2 dan P3. Hal ini menunjukkan penurunan kuantitas susu pada P4 dan kuantitas susu terbanyak pada P1 dan P3. Kuantitas susu pada hari ke-3 menunjukkan P4 berbeda nyata $(\mathrm{p}<0,05)$ dengan $\mathrm{P} 1, \mathrm{P} 2$ dan P3. Hal ini menunjukkan penurunan kuantitas susu pada $\mathrm{P} 4$ dan kuantitas susu terbanyak pada P1. Hasil tersebut menunjukan bahwa perlakuan terbaik yaitu dengan pemberian fodder jagung 25\% dengan pengurangan konsentrat $75 \%$ dan perlakuan tanpa pemberian fodder jagung namun konsentrat tetap diberikan dengan jumlah $100 \%$.

Produksi fooder dapat dihasilkan sepanjang tahun. Penanaman hidroponik sangat mudah dan dapat dilakukan kapan saja, tidak bergantung pada musim karena tanaman yang ditumbuhkan dengan sistem hidroponik tumbuh dalam kondisi tertutup. Namun, kesulitan penanaman di Indonesia karena iklim tropis yang menyebabkan pertumbuhan jamur sangat mudah. Produktivitas ternak salah satunya dipengaruhi oleh kualitas pakan. Kualitas pakan dinilai dari kandungan nutrient dan kecernaaanya. Pakan dengan dengan kualitas dan tingkat kecernaan yang baik memungkinkan ternak mengonsumsi nutrien yang lebih tinggi pada jumlah konsumsi bahan kering yang sama (Agustono dkk, 2017).

Hasil analisis proksimat menunjukan bahwa kadar lemak pada fodder jagung adalah 0,48. Kadar lemak yang terkandung dalam suatu bahan dapat ditentukan dengan cara selisih berat labu lemak akhir dengan berat labu lemak awal, dibagi dengan berat sampel, kemudian dikalikan $100 \%$. Hasil proksimat kadar protein fodder jagung kelompok kami adalah 3,46\%. Kadar air Pada hasil uji laboratorium adalah 88,99\%, sedangkan hasil dari kadar abu menunjukkan kadar abu terbilang cukup tinggi. Artinya semakin banyak mineral yang terkandung didalam jagung tersebut. Semakin kecil kadar abu yang diperoleh, maka kandungan mineral dalam bahan juga akan semakin kecil. Konsumsi pakan merupakan jumlah pakan yang dimakan oleh ternak yang akan digunakan untuk mencukupi kebutuhan pokok dan proses produksi (Tyler dan Ensminger, 2006).

Nutrien yang terserap akan dialirkan melalui darah menjadi prekursor untuk proses sintesis susu di ambing. Manajemen pemberian pakan 
dan minum merupakan salah satu faktor yang mempengaruhi tinggi rendahnya produksi susu pada ternak perah (Taylor dan Field, 2004). Konsumsi pakan yang tinggi mengindikasikan tingkat palatabilitas yang semakin tinggi. Pakan yang diberikan dalam penelitian ini berupa rumput odot, konsentrat dan fodder jagung sebagai perlakuan. Rataan produksi susu setelah pemberian fodder jagung dengan pengurangan konsentrat tidak menunjukan perbedaan nyata. Penggantian konsentrat dengan fodder jagung tidak mempengaruhi produksi susu pada perlakuan P1, P2 dan P3. Hal ini pun kemunginan besar erat kaitannya dengan konsumsi pakan tiap ternak yang berbeda.

Menurut Parakkasi (1999), beberapa faktor yang mempengaruhi tingkat konsumsi pakan selain dari pakan itu sendiri adalah kondisi ternak, kondisi lingkungan dan palatabilitas pakan.

\section{KESIMPULAN}

Kombinasi fodder jagung 25\% dengan $75 \%$ konsentrat dapat menjadi substitusi penggunaan dengan perlakuan $100 \%$ konsentrat tanpa diberikan fodder jagung.

\section{UCAPAN TERIMA KASIH}

Peneliti mengucapkan terima kasih kepada PSDKU Universitas Airlangga Banyuwangi atas dukungan dana yang diberikan untuk melakukan penelitian.

\section{DAFTAR PUSTAKA}

Agustono, B., M. Lamid, A. Ma'ruf, M.T.E. Purnama. 2017. Identifikasi Limbah Pertanian dan Perkebunan sebagai Bahan Pakan Inkonvensional di Banyuwangi. Jurnal Medik Veteriner, 1(1):12-22.

Leng, R.A. 1997. Tree Foliage in Ruminant Nutrition. Animal Production and Health Paper. No. 139. FAO Rome, Italy.

Parakkasi, A. 1999. Ilmu Nutrisi dan Makanan Ternak Ruminant. Universitas Indonesia Press, Jakarta.

Sanchez, M.D. 2002. World distribution and utilization of mulberry and its potential for animal feeding. In Mulberry for Animal Production. ed. M.D.

Taylor, R.E. and T.G. Field. 2004. Scientific Farm Animal Production. 8th Edition. Pearson Prentice Hall Inc., New Jersey.

Tyler, H. and M.E. Ensminger. 2006. Dairy Cattle Science 4 Inc., United States of America.

Yulistiani. 2012. Mulberry Foliage as a Protein Supplement in Dairy Cattle Diet. Institut Pertanian Bogor. Bogor. 